\title{
CAR T cell therapy for breast cancer: harnessing the tumor milieu to drive T cell activation
}

Pradip Bajgain ${ }^{1,2 \dagger}{ }^{1}$ Supannikar Tawinwung ${ }^{1,3+}$, Lindsey D’Elia', Sujita Sukumaran ${ }^{1,2}$, Norihiro Watanabe', Valentina Hoyos ${ }^{1}$, Premal Lulla ${ }^{1}$, Malcolm K. Brenner ${ }^{1}$, Ann M. Leen ${ }^{1}$ and Juan F. Vera ${ }^{1 *}$

\begin{abstract}
Background: The adoptive transfer of T cells redirected to tumor via chimeric antigen receptors (CARs) has produced clinical benefits for the treatment of hematologic diseases. To extend this approach to breast cancer, we generated CAR T cells directed against mucin1 (MUC1), an aberrantly glycosylated neoantigen that is overexpressed by malignant cells and whose expression has been correlated with poor prognosis. Furthermore, to protect our tumortargeted cells from the elevated levels of immune-inhibitory cytokines present in the tumor milieu, we co-expressed an inverted cytokine receptor linking the IL4 receptor exodomain with the IL7 receptor endodomain (4/7ICR) in order to transform the suppressive IL4 signal into one that would enhance the anti-tumor effects of our CAR T cells at the tumor site.
\end{abstract}

Methods: First (1G - CD3Z) and second generation (2G - 41BB.CD3C) MUC1-specific CARs were constructed using the HMFG2 scFv. Following retroviral transduction transgenic expression of the CAR \pm ICR was assessed by flow cytometry. In vitro CAR/ICR T cell function was measured by assessing cell proliferation and short- and long-term cytotoxic activity using MUC1+ MDA MB 468 cells as targets. In vivo anti-tumor activity was assessed using IL4-producing MDA MB 468 tumor-bearing mice using calipers to assess tumor volume and bioluminescence imaging to track $T$ cells.

Results: In the IL4-rich tumor milieu, 1G CAR.MUC1 T cells failed to expand or kill MUC1+ tumors and while coexpression of the 4/7ICR promoted T cell expansion, in the absence of co-stimulatory signals the outgrowing cells exhibited an exhausted phenotype characterized by PD-1 and TIM3 upregulation and failed to control tumor growth. However, by co-expressing 2G CAR.MUC1 (signal 1 - activation + signal 2 - co-stimulation) and 4/7ICR (signal 3 - cytokine), transgenic $T$ cells selectively expanded at the tumor site and produced potent and durable tumor control in vitro and in vivo.

Conclusions: Our findings demonstrate the feasibility of targeting breast cancer using transgenic $T$ cells equipped to thrive in the suppressive tumor milieu and highlight the importance of providing transgenic $T$ cells with signals that recapitulate physiologic TCR signaling - [activation (signal 1), co-stimulation (signal 2) and cytokine support (signal 3)] to promote in vivo persistence and memory formation.

Keywords: Chimeric antigen receptor, Genetic engineering, Inverted cytokine receptor, T cell therapy, Breast cancer

\footnotetext{
* Correspondence: jfvera@txch.org

${ }^{\dagger}$ Equal contributors

${ }^{1}$ Center for Cell and Gene Therapy, Baylor College of Medicine, Texas

Children's Hospital and Houston Methodist Hospital, Houston, TX 77030, USA

Full list of author information is available at the end of the article
}

(c) The Author(s). 2018 Open Access This article is distributed under the terms of the Creative Commons Attribution 4.0 International License (http://creativecommons.org/licenses/by/4.0/), which permits unrestricted use, distribution, and reproduction in any medium, provided you give appropriate credit to the original author(s) and the source, provide a link to the Creative Commons license, and indicate if changes were made. The Creative Commons Public Domain Dedication waiver (http://creativecommons.org/publicdomain/zero/1.0/) applies to the data made available in this article, unless otherwise stated. 


\section{Background}

Breast cancer is the most prevalent malignant disease of women in the developed world and remains one of the leading causes of death; in 2017 an estimated 252,710 new cases of invasive breast cancer were diagnosed in women [1]. Although early detection and advances in conventional chemo-, radio-, and antibody-based therapies have substantially increased cure rates (99\% 5-year survival in patients with localized disease), the 5-year survival of those with distant metastases is only $27 \%$, highlighting the need for novel therapies [1].

The adoptive transfer of $\mathrm{T}$ cells modified to express tumor-targeted chimeric antigen receptors (CARs) has proven to be effective for the treatment of a range of refractory hematologic malignancies including ALL, BCLL, and lymphoma and holds promise for the treatment of solid tumors [2-6]. However, extension of this approach to metastatic breast cancer requires both the identification of an appropriate antigen to target and consideration of additional genetic strategies to protect these cells from the suppressive tumor microenvironment (TME). Indeed, the breast cancer TME is infiltrated by regulatory $\mathrm{T}$ cells $[7,8]$, myeloid-derived suppressor cells (MDSCs) [9, 10], and rich in inhibitory/ Th2-polarized cytokines such as IL4 [11-13], that promote tumor survival [14-17], migration and invasion $[18,19]$, and directly inhibit Th1-polarized effector $\mathrm{T}$ cells [20, 21].

We now explore the feasibility of targeting metastatic breast cancer using $\mathrm{T}$ cells modified with a CAR targeting the tumor associated antigen (TAA) mucin1 (MUC1), whose overexpression in underglycosylated form has been associated with tumor invasiveness and metastatic potential [22-28]. Further, to ensure that our CAR T cells remain operative in the tumor microenvironment, we co-express an inverted cytokine receptor (ICR) encoding the cytokine-binding portion of the IL4 receptor exodomain linked to the immunostimulatory IL7 receptor signaling endodomain (4/7ICR) [29, 30]. We demonstrate the potent, selective, and sustained anti-tumor activity of these dual transgenic $\mathrm{T}$ cells in the IL4-rich breast cancer microenvironment and highlight the importance of transgenically delivering a combination of signals that recapitulate physiological $\mathrm{T}$ cell signaling (activation, co-stimulation, and cytokine support) to ensure durable benefit.

\section{Methods}

\section{Donor and cell lines}

Peripheral blood mononuclear cells (PBMCs) were obtained from healthy volunteers after informed consent on protocols approved by the Baylor College of Medicine Institutional Review Board. The cell lines MDA MB 468, MCF-7, and 293T were obtained from the American Type Culture Collection (Rockville, MD) and were grown in Dulbecco's Modified Eagle Medium (DMEM, GE Healthcare Life Sciences, Pittsburgh, PA) supplemented with $10 \%$ heat-inactivated fetal bovine serum (FBS) (HyClone, Waltham, MA) and $2 \mathrm{mM}$ LGlutaMAX (Gibco BRL Life Technologies, Inc., Gaithersburg, MD). All cell lines were maintained in a humidified atmosphere containing $5 \%$ carbon dioxide $\left(\mathrm{CO}_{2}\right)$ at $37^{\circ} \mathrm{C}$.

\section{Generation of retroviral constructs and retroviral supernatant}

We synthesized a human, codon-optimized 1st generation CAR [31] with specificity against tumorassociated MUC1 using the published HMFG2 scFv sequence [32-34], which was cloned in-frame with the IgG2-CH3 domain (spacer) and the zeta $(\zeta)$ chain of the $\mathrm{T}$ cell receptor (TCR) CD3 complex in an SFG retroviral backbone to make the 1st generation CAR (1G). To generate the 2G.CAR, the 41BB co-stimulatory endodomain was added to the $1 \mathrm{G}$ construct between the CD28 transmembrane and $\zeta$ domains.

To generate the 4/7ICR, we synthesized (DNA 2.0, Menlo Park, CA) a codon-optimized sequence encoding the signal peptide and extracellular domain of the human IL4 receptor $\alpha$ chain fused with the transmembrane and intracellular domain of IL7 receptor, with the restriction sites $X h o 1$ and $M l u 1$ incorporated up and downstream, respectively $[29,30]$. The $4 / 7$ ICR DNA insert was incorporated into an SFG retroviral vector that contained the fluorescent marker mOrange. Retroviral supernatant for both the CARs and 4/7ICR was generated as previously described [29].

\section{Generation of CAR T cells}

To generate CAR T cells, $1 \times 10^{6}$ PBMCs were plated in each well of a non-tissue culture-treated 24-well plate that had been pre-coated with OKT3 $(1 \mathrm{mg} / \mathrm{ml})$ (Ortho Biotech, Inc., Bridgewater, NJ) and CD28 (1 mg/ml) (Becton Dickinson \& Co., Mountain View, CA). Cells were cultured in complete media [RPMI-1640 containing 45\% Clicks medium (Irvine Scientific, Inc., Santa Ana, CA), $10 \% \mathrm{FBS}$, and $2 \mathrm{mM}$ L-GlutaMAX], which was supplemented with recombinant human IL2 $(50 \mathrm{U} / \mathrm{mL}, \mathrm{NIH}, \mathrm{Be}-$ thesda, MD) on day 1 . On day 3 post OKT3/CD28 T blast generation, $1 \mathrm{~mL}$ of retroviral supernatant was added to a non-tissue culture-treated 24-well plate pre-coated with recombinant fibronectin fragment (FN CH-296; Retronectin; Takara Shuzo, Otsu, Japan) and centrifuged at $2000 \mathrm{G}$ for $90 \mathrm{~min}$. OKT3/CD28 activated T cells $\left(0.2 \times 10^{6} / \mathrm{mL}\right)$ were resuspended in complete media supplemented with IL2 $(100 \mathrm{U} / \mathrm{mL})$ and then added to the wells and centrifuged at $400 \mathrm{G}$ for $5 \mathrm{~min}$. To generate CAR and $4 /$ 7ICR co-expressing cells, activated T cells were transduced 
sequentially first with either $1 \mathrm{G}$ or $2 \mathrm{G}$ CAR.MUC1 and then with 4/7ICR on days 3 and 4, respectively. Transduction efficiency was measured 3 days post transduction by flow cytometry.

\section{MDA MB 468 transduction}

We generated an MDA MB 468 cell line that expressed transgenic MUC1 and produced IL4 to ensure homogeneous expression of these molecules. To do this, IL4 cytokine-mOrange retroviral supernatant was plated in a non-tissue culture-treated 24-well plate $(1 \mathrm{ml} /$ well $)$, which was pre-coated with a recombinant fibronectin fragment. MDA MB 468 cells ( 0 . $\left.2 \times 10^{6} / \mathrm{mL}\right)$ were added to the plates $(1 \mathrm{~mL} /$ well $)$ and then transferred to a $37^{\circ} \mathrm{C}, 5 \% \quad \mathrm{CO}_{2}$ incubator. Transgene expression was analyzed by flow 1-week post-transduction and was confirmed by IL4 ELISA (R\&D Systems, Minneapolis, MN), performed per manufacturer instructions. After 2 weeks, these cells were further transduced with a retroviral vector encoding MUC1 [35]. A truncated CD19 (dCD19) [36] was incorporated into the MUC1 vector using an internal ribosome entry site element to facilitate transgene detection. Cells were subsequently sorted based on mOrange and dCD19 expression using a MoFlo flow cytometer (Cytomation, Fort Collins, CO).

\section{Flow cytometry}

The following antibodies were used in this study for $\mathrm{T}$ cell phenotyping: CD3-PerCP (clone SK7/Cat\# 347344), CD25-APC AF700, CD4-Krome Orange (13B8.2/ A96417), CD8-Pacific Blue (B9.11/A82791), CD3-APC (Beckman Coulter Inc. Brea, CA), Rat Anti-Mouse IgG1-APC (X56/550874) (BD Biosciences, San Jose, CA). PD-1-Percp Cy7 and TIM3-APC (BD Biosciences, San Jose, CA) were used as markers of T cell exhaustion. MUC1 antigen expression by tumor cells was measured using anti-MUC1, (Santa Cruz Biotechnology. Inc., Dallas, TX). CAR molecules were detected using Goat anti-human $\mathrm{F}\left(\mathrm{ab}^{\prime}\right) 2$ antibody conjugated with AlexaFluor647 (109-606-097) (Jackson ImmunoResearch Laboratories, Inc., West Grove, PA). Cells were stained with saturating amounts of antibody $(\sim 5 \mathrm{uL})$ for $20 \mathrm{~min}$ at $4{ }^{\circ} \mathrm{C}$, washed (PBS, Sigma-Alrich, St. Louis, MO), and then acquired on Gallios ${ }^{\mathrm{TM}}$ Flow Cytometer (Beckman Coulter Inc., Brea, CA). Analysis was performed using Kaluza ${ }^{\oplus}$ Flow Analysis Software (Beckman Coulter Inc.).

\section{${ }^{51}$ Chromium-release assay}

The cytotoxicity and specificity of engineered T cells was evaluated in a standard $4-6 \mathrm{hr}{ }^{51} \mathrm{Cr}$-release assay, as previously described [37].

\section{T cell stimulation assay}

To measure $\mathrm{T}$ cell expansion upon antigen stimulation in the presence of IL4 cytokine $(400 \mathrm{pg} / \mathrm{mL})$ (R\&D Systems, Minneapolis, MN), $1 \times 10^{6}$ CAR.MUC1 T cells were cultured with $0.5 \times 10^{6}$ irradiated MDA MB 468 tumor cells engineered to overexpress MUC1. Tumor cells were irradiated (100Gy) to halt their expansion using Rad Source RS2000 Biological X-Ray Irradiator (Rad Source Technologies, Buford, GA). IL4 was added to culture 2 times per week and T cells were quantified by trypan blue exclusion.

\section{Co-culture experiments}

For co-culture experiments, eGFP-FFLuc+ MDA MB 468 overexpressing MUC1 $\left(1 \times 10^{6}\right.$ cells $)$ were inoculated into $3 \mathrm{D}$ algimatrix bioscaffold (Thermo Fisher Scientific, Inc., Waltham, MA) and cultured in 6well G-Rex [38] devices (Wilson Wolf Manufacturing, New Brighton, MN). Three days later, CAR or CAR +ICR-modified $\mathrm{T}$ cells were added to tumor cells to achieve a $\mathrm{T}$ cell:tumor cell ratio of 1:10 in the presence of $400 \mathrm{U} / \mathrm{mL}$ IL4. Anti-tumor activity was monitored using the IVIS Lumina In Vivo Imaging system (Caliper Life Sciences, Hopkinton, MA) $10 \mathrm{~min}$ after adding Dluciferin (PerkinElmer, Waltham, MA) (15 mg/mL) into the culture media. Cells were then collected and recovered from the Algimatrix using Aligmatrix dissolving buffer (Thermo Fisher Scientific, Inc.). To quantify cells by flow cytometry, we used CountBright ${ }^{\mathrm{Tm}}$ Absolute Counting Beads (C36950; Invitrogen, Eugene, OR) and 7-AAD was added to exclude dead cells. Acquisition was halted at 5000 beads. T cells were then purified using CD3 microbead column (MACS) for subsequent ${ }^{51} \mathrm{Cr}$ release assay.

\section{In vivo study}

Six to eight-week-old female NSG mice (NOD.CgPrkdcscid Il2rgtm1Wjl/SzJ, Jackson ImmunoResearch Laboratories, Inc., West Grove, PA) were injected with $5 \times 10^{6}$ IL4 cytokine-producing, MUC1-overexpressing MDA MB 468 (MDA MB 468/IL4) cells suspended in $50 \% \mathrm{DPBS} / 50 \%$ matrigel subcutaneously (s.c.) into the left inferior mammary fat pad. Once the tumor reached a size of approx. $75 \mathrm{~mm}^{3}$ ( 4-5 weeks), animals were injected intravenously (i.v.) with $3 \times 10^{6}$ eGFP-FFLuc +1G, 1G.4/7ICR, 2G, or 2G.4/7ICR T cells. Tumor size was measured by bi-weekly caliper measurement and tumor volume $\left(\mathrm{mm}^{3}\right)$ was calculated by length $\mathrm{x}$ width $\mathrm{x}$ width $/ 2$. T cell expansion and persistence was monitored using the IVIS Lumina In Vivo Imaging system (Caliper Life Sciences, Hopkinton, MA) 10 min after injection (i.p.) with $100 \mathrm{ul}$ of D-luciferin $(15 \mathrm{mg} / \mathrm{mL})$. All in vivo analysis was performed using Living Image software (Caliper Life Sciences, Inc., Hopkinton, MA). 
a

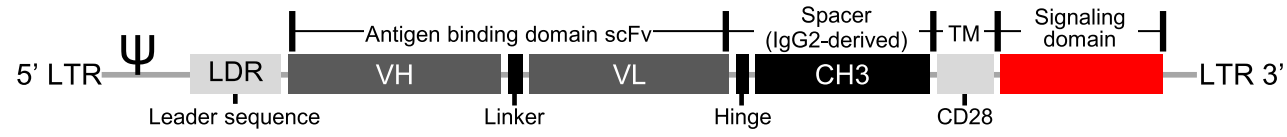

b
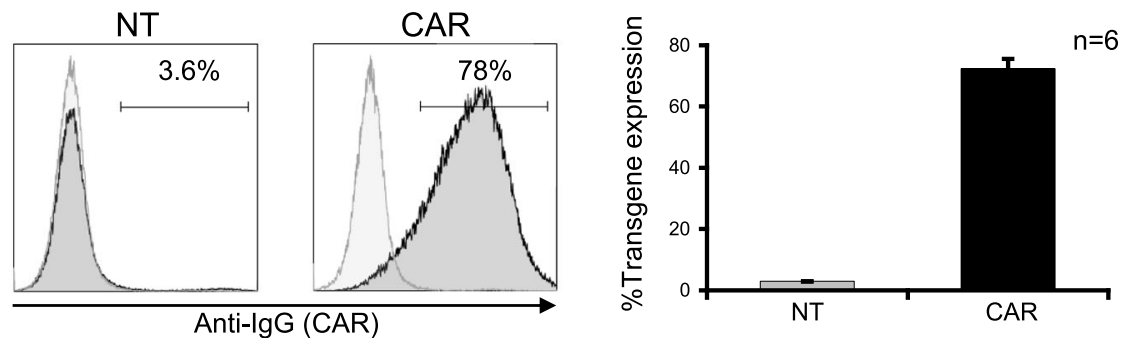

C
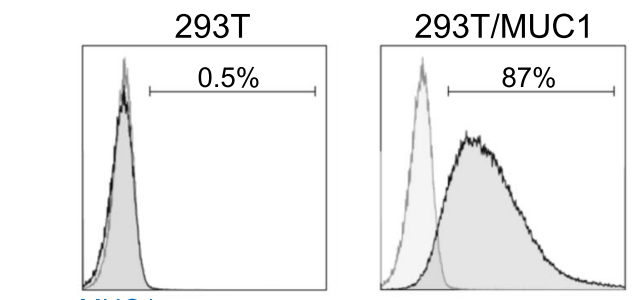

MDA MB 468
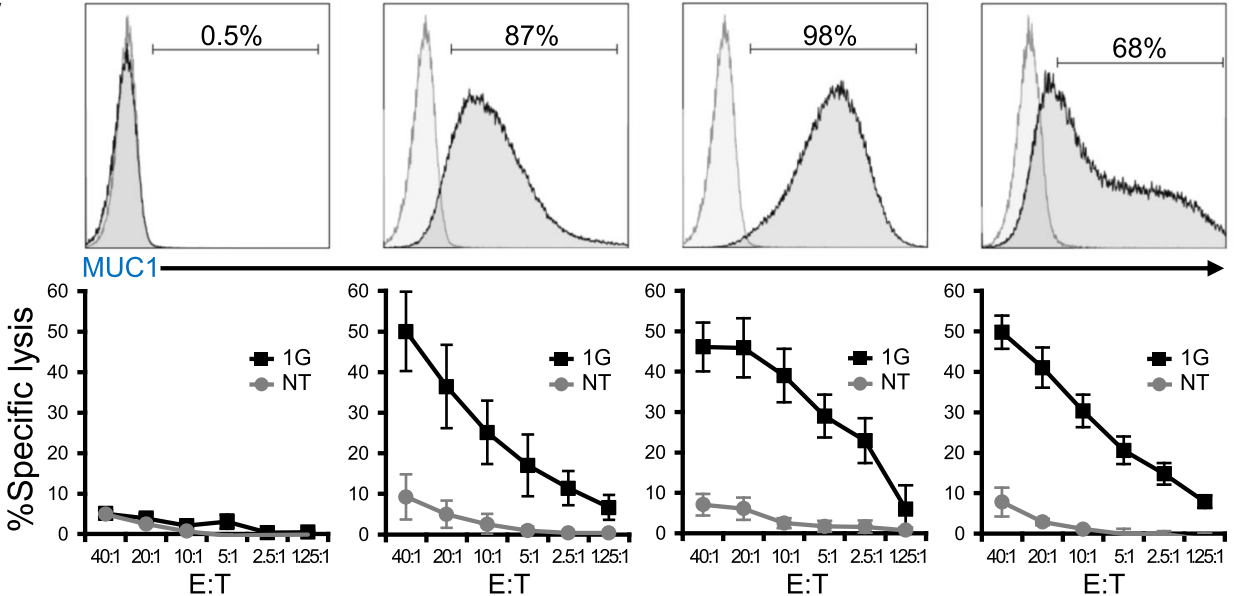

d

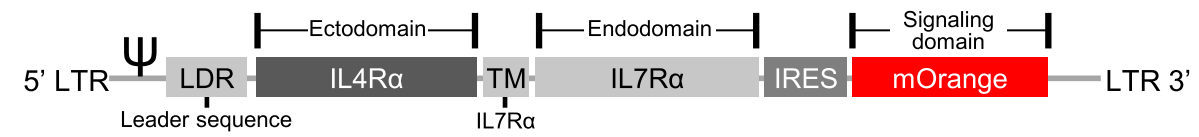

e
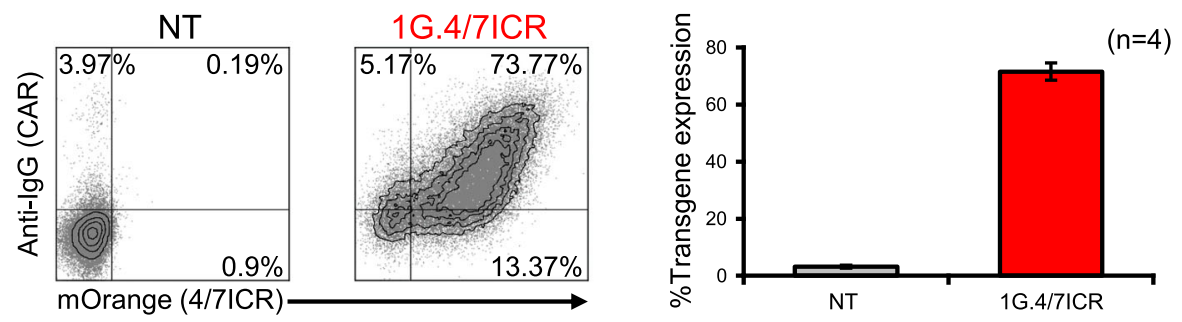

f
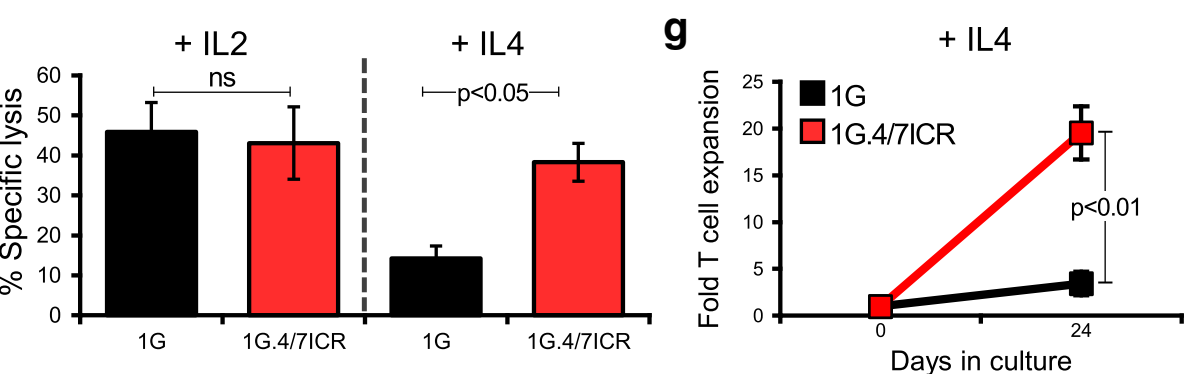

Fig. 1 (See legend on next page.) 
(See figure on previous page.)

Fig. 1 4/7ICR improves the cytolytic function and proliferation of CAR.MUC1 T cells in presence of IL4. a Schematic representation of 1st generation CAR.MUC1 (1G) construct. b CAR.MUC1 expression on activated T cells measured 3 days post-transduction (representative donor on the left, summary data on the right). Data represents mean \pm SEM $(n=6)$. c Phenotypic analysis of MUC1 expression on different cell lines (top panel) and in vitro cytolytic function of control (NT) and CAR T cells assessed in a $5 \mathrm{hr}{ }^{51} \mathrm{Cr}$-release assay at E:Ts of 1.25:1 to 40:1, using MUC1+ targets (293T/ MUC1, MDA MB 468, MCF-7) and MUC1- target (293T) (bottom). Data represents mean \pm SEM $(n=5)$. d Schematic of 4/7ICR vector map. e Transgenic expression of both 4/7ICR and CAR.MUC1 in T cells as detected by mOrange and anti-lgG, respectively. Right panel shows summary data representing the percentage of double-positive cells (1G.4/7ICR) (mean \pm SEM, $n=4$ ). $\mathbf{f}$ Cytolytic function of transgenic (1G or 1G.4/7ICR) T cells pre-exposed to IL4 as assessed in a $4 \mathrm{hr}^{51} \mathrm{Cr}$-release assay using MDA MB 468 as a target at the indicated E:T ratios. Statistical significance was calculated between $1 \mathrm{G}$ and 1G.4/7ICR using One-way ANOVA, $p<0.05$. g Cell expansion of $1 \mathrm{G}$ or $1 \mathrm{G} .4 / 7 \mathrm{ICR}$ T cells $\left(1 \times 10^{6}\right)$ stimulated weekly with irradiated MDA MB 468 cells $\left(0.5 \times 10^{6}\right)$ with IL4 $(400 \mathrm{U} / \mathrm{mL})$ added twice weekly. T cell expansion was quantified by cell counting using trypan blue exclusion to assess cell viability. Statistical significance was calculated between $1 \mathrm{G}$ and 1G.4/7ICR using One-way ANOVA, $p<0.01$

Experiments were performed according to Baylor College of Animal Husbandry guidelines.

\section{Statistical analysis}

Results are reported as mean \pm SEM unless stated otherwise. All statistical analyses were performed using GraphPad Prism software. Statistical significance between/ among groups were determined using one-way ANOVA, two-way ANOVA, or unpaired two-tailed t tests. $P$-values less than 0.05 were considered statistically significant.

\section{Results}

4/7ICR improves the cytolytic function and proliferation of CAR.MUC1 T cells in presence of IL4

To target breast cancer, we generated a retroviral vector encoding a first-generation human, codon-optimized CAR (1G) directed against the tumor-associated antigen MUC1 (Fig. 1a) [35]. This transgenic molecule could be stably expressed on activated T cells (mean $72.3 \pm 1.9 \%$ transduction efficiency, Fig. 1b), enabling CAR T cells to specifically kill MUC1-expressing tumors (293T/MUC1, MDA MB 468, and MCF-7) with no recognition of MUC1 negative targets (293T) (Fig. 1c). In the breast cancer tumor microenvironment, antigen-specific $\mathrm{T}$ cells can be rendered dysfunctional following chronic exposure to immunosuppressive cytokines. These include IL4, which is elevated in patients with breast cancer [11-13]. To ensure that our CAR.MUC1 T cells persist and remain functional at the tumor site, we developed an inverted chimeric cytokine receptor "4/7ICR" (Fig. 1d) containing the cytokine-binding portion of the IL4 receptor linked with the signaling endodomain of IL7 receptor, which we co-expressed with 1G CAR [Fig. 1e -mean $71.5 \pm 3 \%$ double positive (1G.4/7ICR) $\mathrm{T}$ cells]. To test if the 4/7ICR enabled CAR T cells to withstand the inhibitory effects of IL4, we cultured $1 \mathrm{G}$ or 1G.4/ 7ICR T cells with either IL2 or IL4 for 14 days and subsequently assessed their cytolytic function in a $4 \mathrm{hr}{ }^{51} \mathrm{Cr}$ release assay using MDA MB 468 cells as targets. As shown in Fig. 1f, there was no difference between the cytolytic potential of $1 \mathrm{G}$ or 1 G.4/7ICR $\mathrm{T}$ cells cultured with IL2. However, when exposed to IL4, the cytolytic capacity of unprotected $1 \mathrm{G}$ T cells was significantly less than that of 1 G.4/7ICR T cells $(14.2 \pm 3.2 \%$ vs $38.3 \pm 4$. $8 \%$ specific lysis, E:T ratio $20: 1 ; p<0.05)$. Similarly, the expansion of 1 G.4/7ICR T cells was superior to their $1 \mathrm{G}$ counterparts when we cultured both in the presence of recombinant IL4 with weekly antigen stimulation from irradiated MDA MB 468 tumor cells (Fig. 1g).

\section{Transgenic expression of 4/7ICR is insufficient to overcome tumor-mediated $\mathrm{T}$ cell dysfunction}

We next explored whether co-expression of the 4/7ICR and the $1 \mathrm{G}$ CAR produced superior anti-tumor effects in a long-term tumor model that recapitulated an IL4rich milieu. We co-cultured GFP-firefly luciferase (eGFP-FFLuc) labeled MDA MB 468 breast cancer cells with either $1 \mathrm{G}$ or $1 \mathrm{G} .4 / 7 \mathrm{ICR} \mathrm{T}$ cells at an effector-totarget (E:T) ratio of $1: 10$ in the presence of IL4 (400 U/ $\mathrm{mL}$ ), monitoring anti-tumor activity by bioluminescence imaging (Fig. 2a). When 1G.4/7ICR T cells were exposed to tumor milieu conditions, they expanded in vitro during the 3-week co-culture (Fig. 2b), but unexpectedly failed to produce superior anti-tumor activity (Fig. 2c). To explore the mechanism of failure, we examined both the tumor and 1G.4/7ICR T cells before and after treatment and saw no change in either MUC1 antigen expression on malignant cells (Fig. 2d) or CAR expression by the T cells (Fig. 2e). Additionally, we confirmed that 1G.4/7ICR cells (unlike their $1 \mathrm{G}$ counterparts) retained an activated (CD25+) phenotype (Fig. 2f), confirming lack of inhibition by prolonged IL4 exposure. However, we observed a progressive increase in PD-1 and TIM3 expression over time (Fig. 2g), which inversely correlated with cytolytic function of $\mathrm{T}$ cells extracted on day 21 of the co-culture, as shown in Fig. 2h (day 0 vs day 21). Taken together, these data show that transgenic expression of the 4/7ICR was insufficient to protect CAR.MUC1 T cells from tumor-mediated dysfunction.

Combining 4/7ICR with a $2 \mathrm{G}$ CAR preserves T cell function even under suppressive conditions

$\mathrm{T}$ cells require 3 signals (antigen - signal 1; costimulation - signal 2; cytokine - signal 3) for optimal 


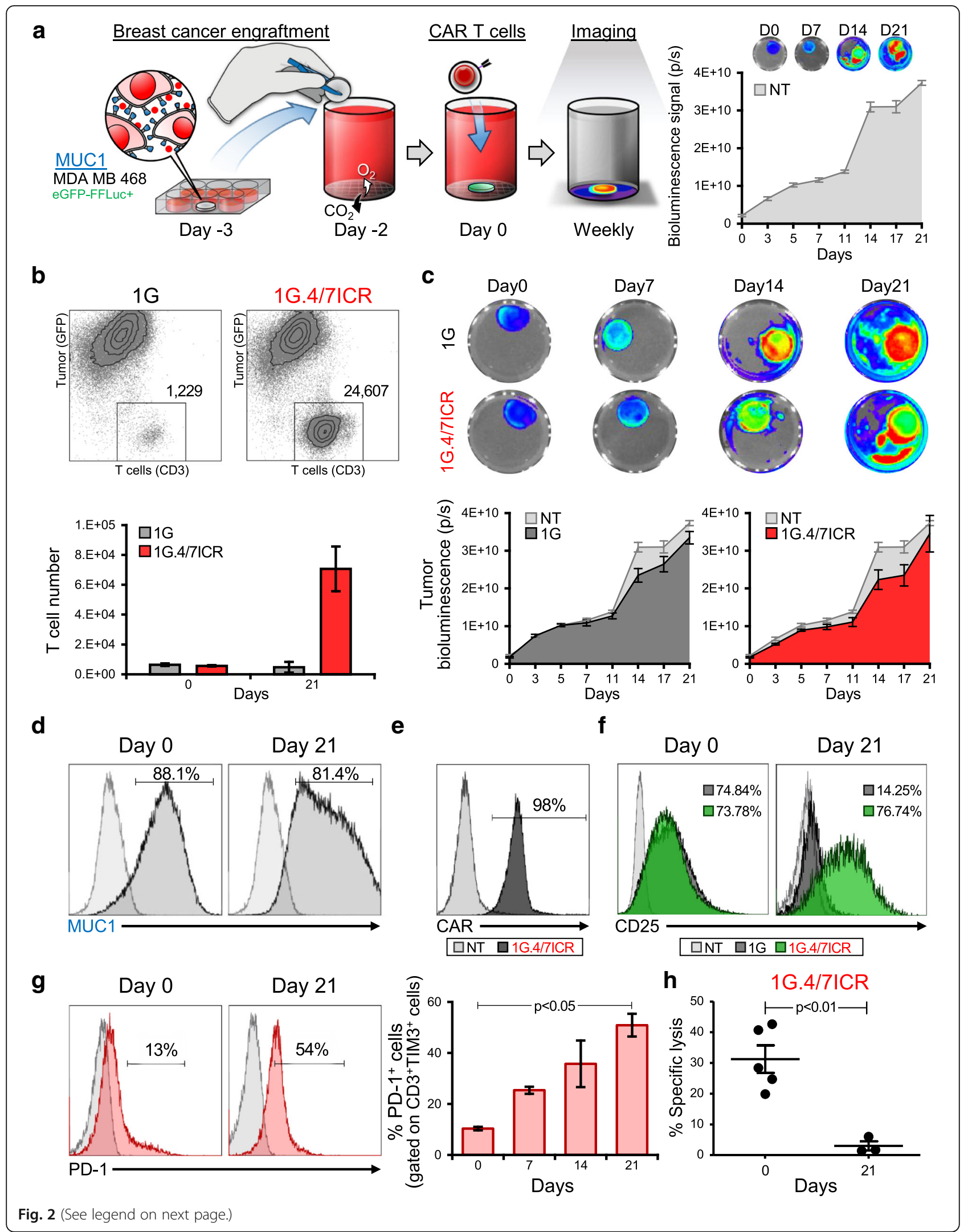


(See figure on previous page.)

Fig. 2 Transgenic expression of 4/7ICR is insufficient to overcome tumor-mediated T cell dysfunction. a Schematic of co-culture experimental setup (left panel) and bioluminescence data tracking tumor expansion (in the absence of T cell treatment) over time (right panel). b Representative dot plots (top) and summary quantitative data (bottom) showing $T$ cells and tumor cell numbers on day 0 and day 21 of coculture (mean $\pm \mathrm{SEM}, \mathrm{n}=6$ independent experiments). Significance was determined by an unpaired two-tailed t-test, $\mathrm{p}<0.05,1 \mathrm{G} .4 / 7 \mathrm{ICR}$ compared with 1G. c Representative images of bioluminescent tumor cells (top) and summarized quantitative bioluminescence signal from tumor cells treated with either NT, $1 \mathrm{G}$ or $1 \mathrm{G} .4 / 7 \mathrm{ICR}$ T cells over time (mean $\pm \mathrm{SEM}, \mathrm{n}=6$ ). $\mathbf{d}$ Phenotypic analysis of MUC1 expression on MDA MB 468 cells on day 0 and day 21 of co-culture (representative donor). e CAR expression on 1G.4/7ICR cells after co-culture with tumor cells. $\mathbf{f}$ CD25 expression on 1G versus 1G.4/7ICR T cells on day 0 and day 21 of co-culture (light grey: isotype control, dark grey: 1G T cells, green: 1G.4/7ICR T cells). g Surface expression of PD-1 (representative donor - left, summary data - right) on 1G.4/7ICR cells gated on $\mathrm{CD}^{+} \mathrm{TIM}^{+}$cells and analyzed on days $0,7,14$ and 21 of co-culture (mean $\pm S E M, n=6, p<0.05$ ). $\mathbf{h}$ Cytolytic activity of $1 \mathrm{G} .4 / 7 / / C R$ prior to and day 21 post-coculture using MDA MB 468 cells as targets (E:T 10:1; mean \pm SEM, $n=4, p<0.01$ )

effector function and persistence in an activated state [39-41]. To determine whether the $\mathrm{T}$ cell exhaustion we detected in our 1G.4/7ICR cells could be overcome by incorporating a co-stimulatory signal, we constructed a 2nd generation CAR.MUC1 (2G) which contained both the CD3 zeta chain (signal 1) and a 41BB endodomain (signal 2) and could be efficiently co-expressed with the 4/7ICR (Additional file 1: Figure S1). We then compared the phenotype and function of $1 \mathrm{G}$ (signal 1 only), 1G.4/ 7ICR (signals $1+3$ ), $2 \mathrm{G}$ (signal $1+2$ ), and 2G.4/7ICR (signals $1+2+3$ ) $\mathrm{T}$ cells when co-cultured with MDA MB 468 breast cancer cells in the presence of IL4 (400 U/mL) (Fig. 3). Consistent with previous observations, 1G T cells failed to expand and control tumors; while 1G.4/7ICR expanded, they were similarly unable to mediate anti-tumor effects (Fig. 3a and b). Combining signals 1 and 2 also did not produce superior $\mathrm{T}$ cell antitumor effects (Fig. 3a and b). In contrast, co-expression of $2 \mathrm{G}$ CAR and the 4/7ICR, which provides all 3 signals required for physiologic $\mathrm{T}$ cell activation and persistence, resulted in potent $\mathrm{T}$ cell expansion and anti-tumor activity (Fig. 3a and b), leading to durable control. Assessment of $\mathrm{T}$ cell phenotype post-co-culture (day 21) demonstrated a decreased expression of PD-1 and TIM3 by 2 G.4/7ICR cells compared to 1G.4/7ICR $\mathrm{T}$ cells (Fig. 3c), and an increased expression of the activation marker CD25 (Fig. 3d). This phenotype of 2G.4/ 7ICR $\mathrm{T}$ cells correlated with their ability to kill (specific lysis of $19.9 \pm 1.4 \%$; E:T ratio of 10:1, $n=4$, Fig. 3e) tumor cells even after a long-term (21 days) exposure to the tumor cells, while the 1G.4/7ICR and $2 \mathrm{G}$ cells exhibited diminished cytolytic activity $(3.0 \pm 1.6 \%$ and $3.7 \pm 0.9 \%$ specific lysis respectively; E:T ratio of 10:1, $\mathrm{n}=4$, Fig. 3e).

\section{Combined expression of 4/7ICR and 2G CAR augments anti-tumor activity in vivo}

To determine whether the potent anti-tumor effects observed when combining the $2 \mathrm{G}$ CAR with 4/7ICR would be recapitulated in vivo, NSG mice were engrafted (s.c. in the left inferior mammary fat pad) with
$5 \times 10^{6}$ IL4-producing MDA MB 468 cells (MDA MB 468/IL4) (Fig. 4a). Once the tumor had reached approx. $75 \mathrm{~mm}^{3}$ ( $\sim 4-5$ weeks post-engraftment), animals were treated with $3 \times 10^{6}$ eGFP-FFLuc+1G, 1G.4/7ICR, 2G, or 2G.4/7ICR $\mathrm{T}$ cells and tracked in vivo by bioluminescence imaging. As shown in Fig. $4 \mathrm{~b}$ and $\mathrm{d}, \mathrm{T}$ cells localized at the tumor site in every group (left panel - individual examples; right panel - summary data). However, in mice treated with $1 \mathrm{G}$, the $\mathrm{T}$ cells failed to expand (change in bioluminescence from $2.6 \pm 0.35 \mathrm{E}+07$ photons/sec, day 0 to $1.69 \pm 0.51 \mathrm{E}+09$ photons/sec, day 28) and the tumor rapidly outgrew (Fig. 4c). Similarly, in the 2G-treated group the tumor outgrew despite $T$ cell expansion (Fig. 4e). In contrast, within 5 weeks of treatment, we observed a reduction in tumor in both cohorts receiving 4/7ICR-modified T cells (Fig. 4c and e). However, while none of the 1G.4/7ICR-treated animals were tumor-free, every mouse receiving 2G.4/7ICR T cells was tumor-free and remained so for an additional 4 weeks. Importantly, upon tumor clearance, the numbers of 2G.4/7ICR T cells rapidly declined (decrease in $\mathrm{T}$ cell signal from $2.0 \pm 0$. $48 \mathrm{E}+10$ to $6.21 \pm 2.1 \mathrm{E}+08$ photons/sec between days 14 and 35; Fig. 4d), indicating that sustained expansion required both antigen and cytokine, and supporting the safety of the approach.

\section{G.4/7ICR T cells persist long term and retain their anti- tumor activity and tumor selectivity}

To assess in vivo persistence and evaluate the tumor selectivity of our 2G.4/7ICR T cells, we rechallenged animals who had initially cleared their IL4-producing tumors (Fig. 4) with $5 \times 10^{6}$ MDA MB 468 cells (right superior mammary fat pad) or $5 \times 10^{6}$ IL4-producing MDA MB 468 cells (MDA MB 468/IL4) on the left superior mammary fat pad (Fig. 5a). As shown in Fig. 5b, tumor rechallenge selectively induced 2G.4/7ICR T cell re-expansion only at the site engrafted with IL4producing tumor, leading to tumor rejection on that side but contralateral tumor outgrowth (Fig. 5c). These data further illustrate the persistence, proliferative capacity, potency, and cytokine dependency of 2G.4/7ICR T cells. 

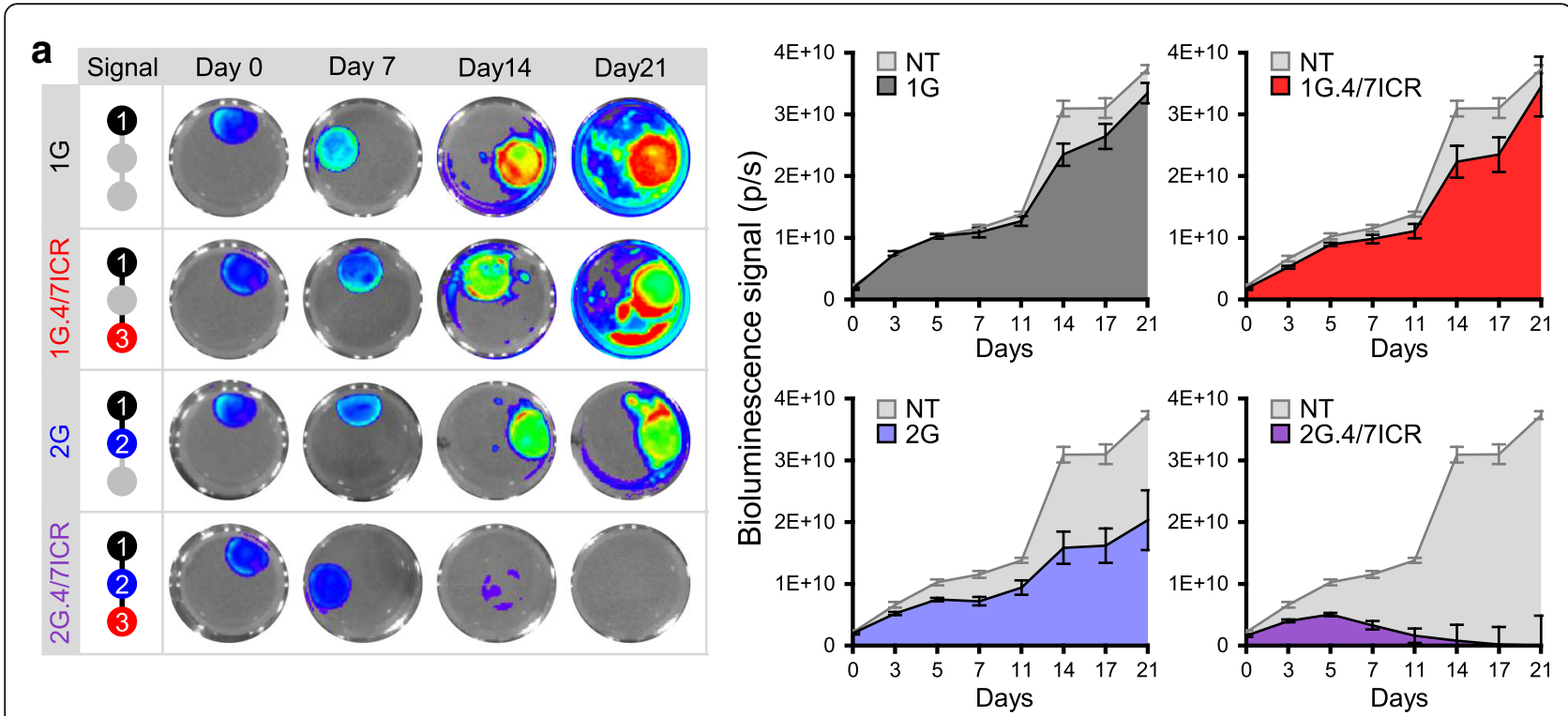

b
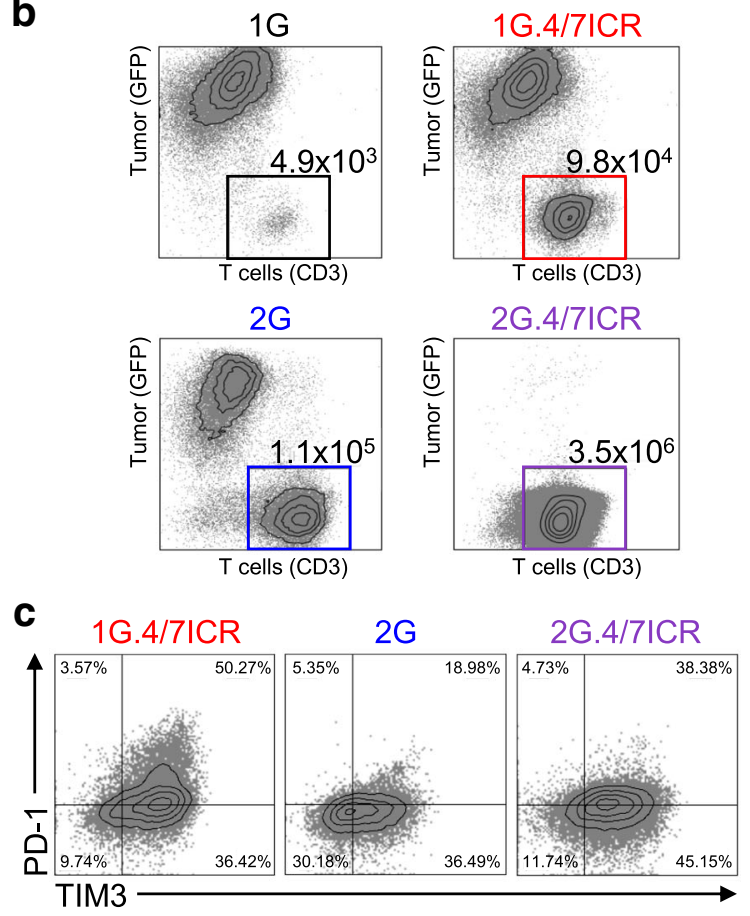

d

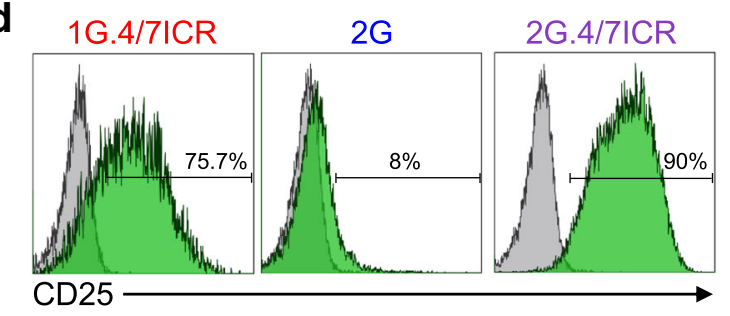

1G.4/7ICR
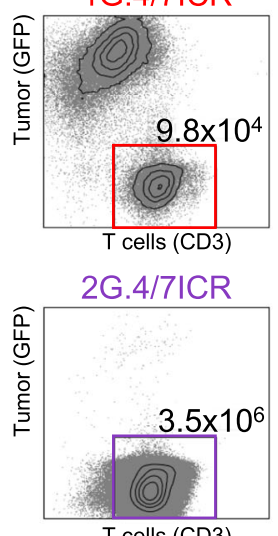
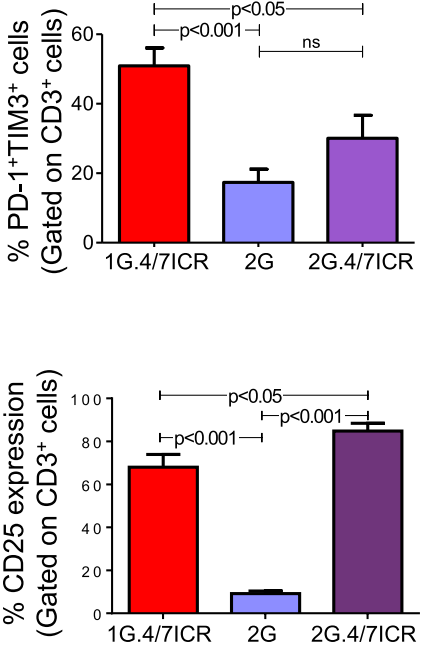

Fig. 3 (See legend on next page.)

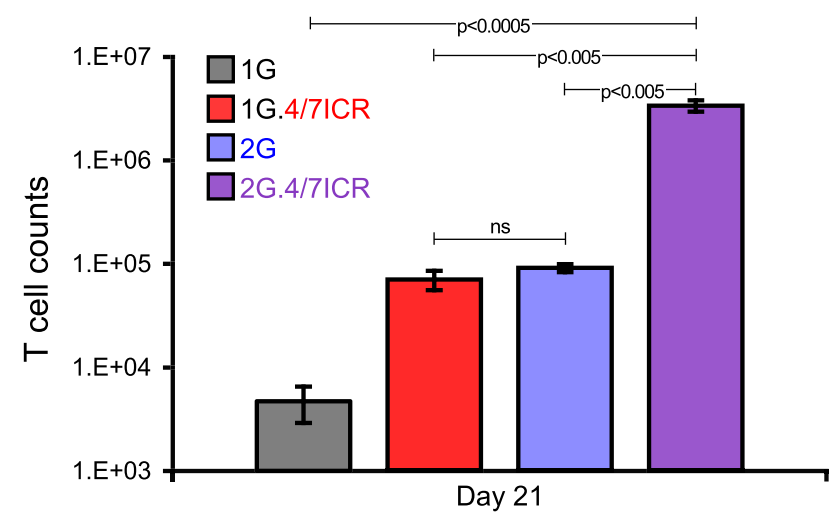

e

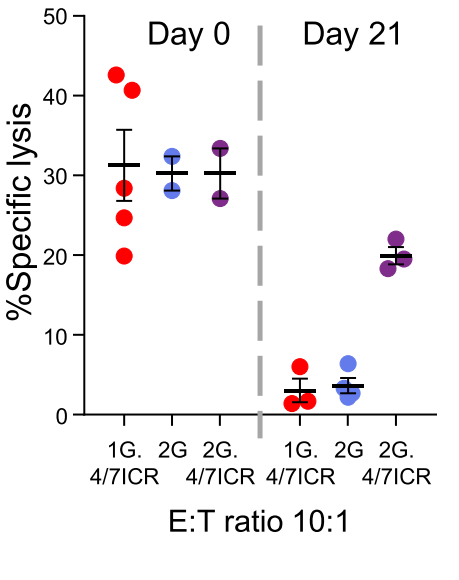


(See figure on previous page.)

Fig. 3 Combining 4/7ICR with a 2G CAR preserves T cell function even under suppressive conditions. a Serial bioluminescence imaging of eGFPFFLuc ${ }^{+}$MDA MB 468 cells co-cultured with 1G, 1G.4/7ICR, 2G, or 2G.4/7ICR T cells in the presence of IL4 [representative images - left, quantitative data - right $(n=6)$ ]. b Representative dot plots and summary FACS data quantifying tumor cells and T cells after 21 days of co-culture. c Surface expression of PD-1 and TIM3 on transgenic T cells analyzed on day 21 after co-culture (representative data - left, summary data - right). d CD25 expression on 1G.4/7ICR, 2G, and 2G.4/7ICR cells on day 21 of coculture. e In vitro cytolytic function of 1G.4/7ICR, 2G, and 2G.4/7ICR cells isolated on day 21 after co-culture (mean \pm SEM, $n=4-6$ ). Significance was determined by two-way ANOVA. $p<0.05, p<0.01, p<0.001$

\section{Discussion}

In the current study, we improved the potency of breast cancer-specific $\mathrm{T}$ cells by co-expressing an inverted cytokine receptor (ICR) on CAR T cells targeting MUC1. This combination of modifications: (i) protected transgenic cells from the inhibitory effects of IL4, (ii) enhanced $\mathrm{T}$ cell expansion at the tumor site, and (iii) improved the in vitro and in vivo anti-tumor activity of transgenic cells. Importantly, the 4/7ICR did not alter the antigen specificity of the CAR and withdrawal of

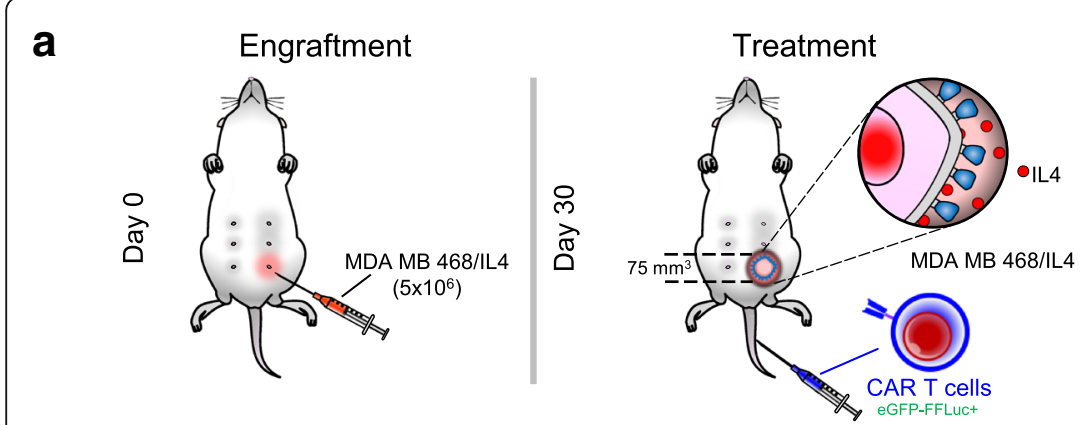

b
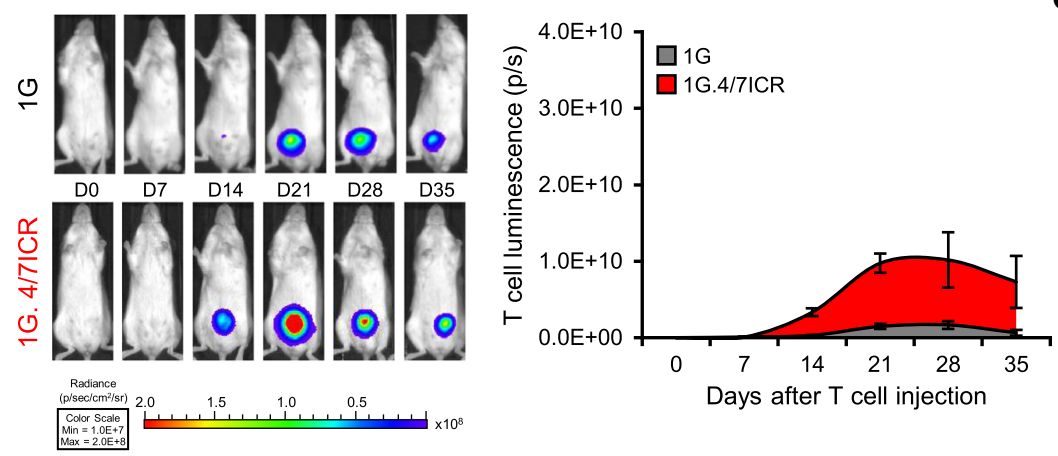

C

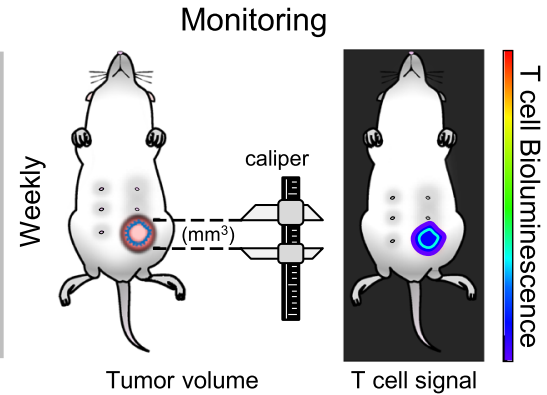

d
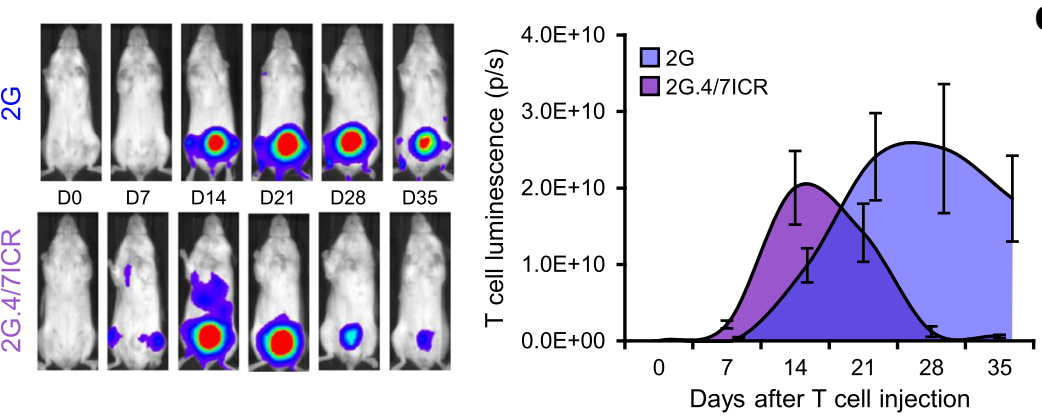

e
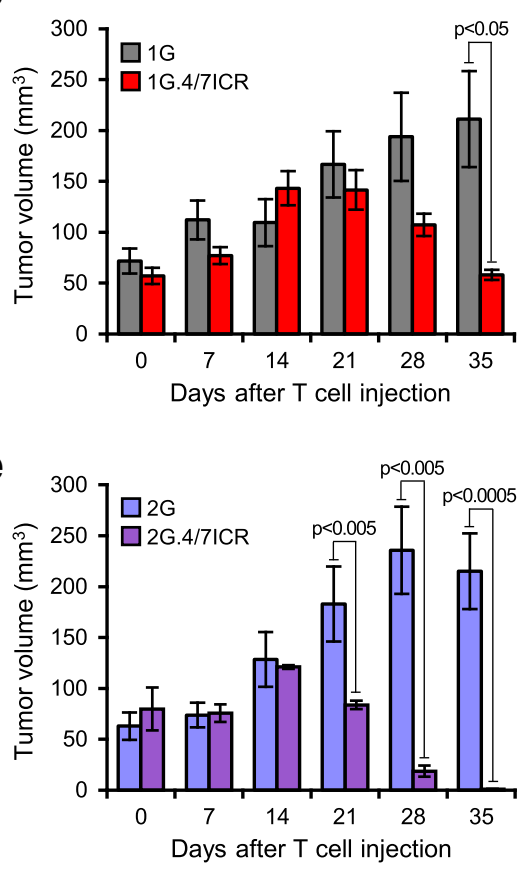

Fig. 4 Combined expression of 4/7ICR and 2G CAR augments anti-tumor activity in vivo. a Schematic of in vivo experiment where NSG mice with IL4-producing MDA MB 468 cells and treated i.v. with eGFP-FFLuc+1G, 1G.4/7ICR, 2G, or 2G.4/7ICR T cells. b Representative animal images (left) and summary bioluminescence data (right, mean \pm SEM, $n=3-5$ /group) indicating T cell localization and expansion. c Tumor volume measured by calipers (mean \pm SEM, $n=3-5 /$ group). Significance was determined by two-way ANOVA. $p<0.05$ on day 35. $\mathbf{d}$ Representative animal images (left) and summary bioluminescence data (right, mean \pm SEM, $n=3-5$ /group). e Tumor volume measured by calipers. Significance was determined by two-way ANOVA 


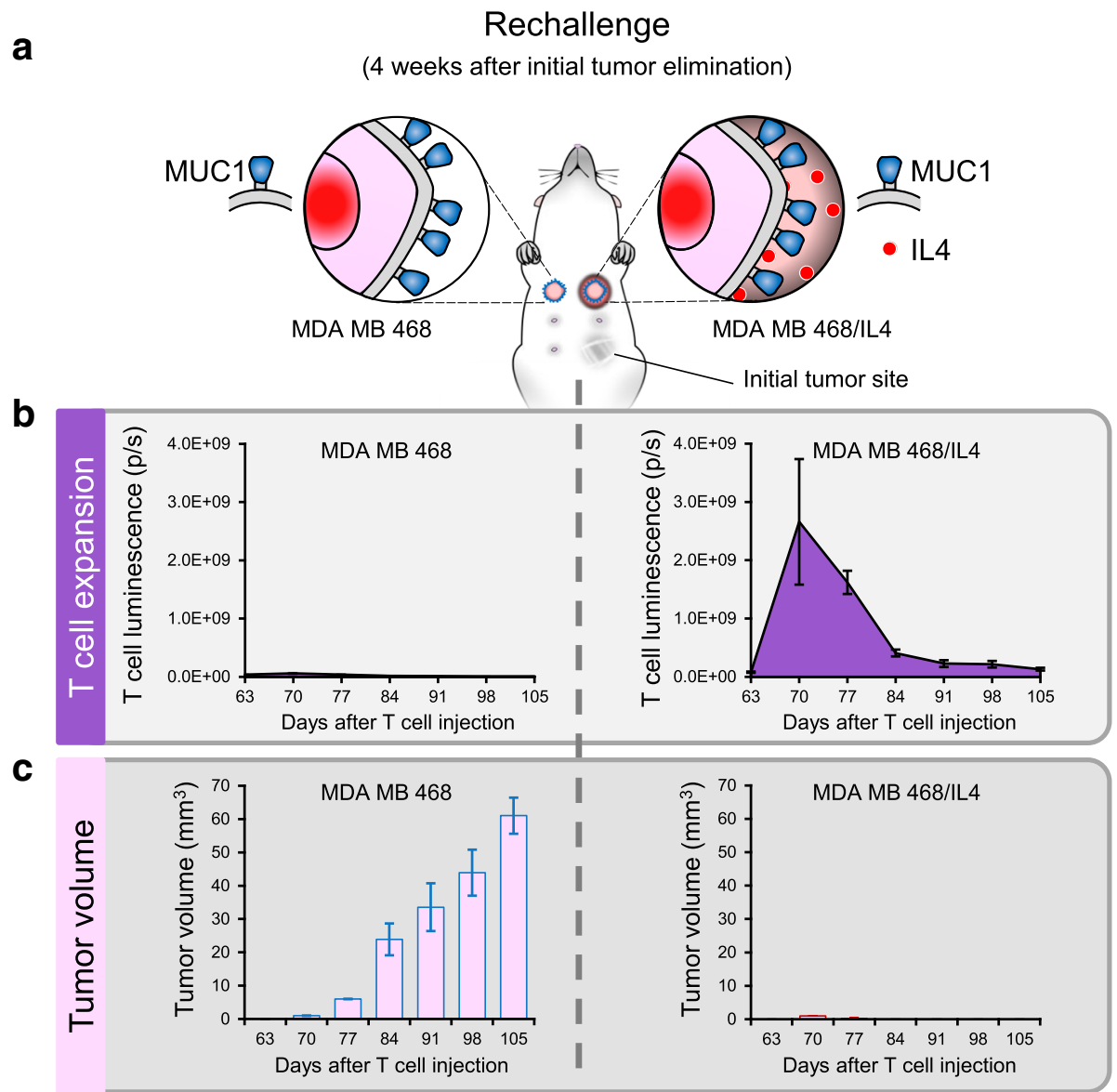

Fig. 5 2G.4/7ICR T cells persist long term and retain their anti-tumor activity and tumor selectivity. a Schema of tumor rechallenge model. $\mathbf{b} T$ cell expansion over time as assessed by quantitative bioluminescence imaging at the site of MDA MB 468 (left) and MDA MB 468/IL4 (right) tumor cell injection. c Tumor volume as measured by calipers

either antigen or cytokine resulted in rapid $\mathrm{T}$ cell contraction, confirming the safety of this strategy for clinical translation.

In nature, $\mathrm{T}$ cells require the presence of 3 signals [antigen recognition (signal 1), co-stimulation (signal 2), and cytokine (signal 3)] for potent activation and long-term memory formation, while the absence of any one of these signals substantially impairs $\mathrm{T}$ cell function [40, 41]. Indeed, this feature has been exploited clinically in recipients of allogeneic stem cell transplants where alloreactive (GvHD-inducing) $\mathrm{T}$ cell activity was blunted by blocking the costimulatory CD28 signal [42]. In the current study, we saw similar dysfunction in our transgenic $\mathrm{T}$ cells modified to express a first-generation CAR and the 4/ 7ICR, which provided T cells with signals 1 and 3, respectively. In absence of co-stimulation, our cells displayed an exhausted phenotype, characterized by the upregulation of PD-1/TIM3 and diminished cytolytic function. $T$ cells that received just signals $1+2$ (2G CAR.MUC1) were similarly dysfunctional and unable to produce tumor control. However, by engineering $\mathrm{T}$ cells to receive all 3 signals [ $\mathrm{T}$ cell activation (signal 1) and co-stimulation (signal 2) - provided by the $2 \mathrm{G}$ CAR.MUC1 and cytokine support (signal 3) - provided by the $4 / 7 \mathrm{ICR}]$, we were able to achieve sustained $\mathrm{T}$ cell responses, highlighting the importance of recapitulating physiologic $\mathrm{T}$ cell signaling in a transgenic cell in order to produce durable antitumor effects.

To develop an immunotherapeutic approach for breast cancer, we chose to target an aberrantly glycosylated form of MUC1, which represents a cancerexpressed neoantigen that can be selectively targeted by antibodies and CARs, thereby alleviating concerns associated with "on target off tumor" toxicities [43]. MUC1 was first validated as a transgenic $\mathrm{T}$ cell target by Wilkie and colleagues who developed a CAR targeting epitopes in the variable number tandem repeat (VNTR) region that were unmasked due to underglycosylation [32, 44, 45]. Subsequently, June et al. generated a CAR targeting a tumor-specific glycoform 
(MUC1-Tn), which selectively targeted a range of MUC1+ tumors (leukemia, pancreatic cancer and breast cancer) leaving normal cells including cardiomyocytes, osteoblasts, renal epithelial cells and pulmonary artery endothelial cells untouched [46].

To next ensure that our MUC1-targeted $\mathrm{T}$ cells retained effector function in the suppressive tumor microenvironment, we paired our CAR with a chimeric receptor designed to harness and invert the inhibitory effects of tumor-produced IL4. In breast cancer, IL4 is a dominant component of the tumor microenvironment produced both by malignant cells and surrounding adipose tissue [17, 47]. This prototypic Th2 cytokine directly induces the upregulation of anti-apoptotic molecules in malignant cells but also suppresses the effector function of Th1-polarized T cells (Fig. 1 and refs. [14-21]). Hence, we hypothesized that transgenic expression of the 4/7ICR would serve not just to protect our CAR $\mathrm{T}$ cells from the inhibitory effects of IL4 (due to the ICR exodomain), but additionally promote their expansion at the tumor site. This proliferative signal is provided to our transgenic cells, courtesy of the IL7 receptor endodomain, which we chose to include given the importance of IL7 signaling in homeostatic proliferation and the maintenance of $\mathrm{T}$ cell memory [48-50]. Hence, upon IL4 engagement, our 4/7ICR delivers a prototypic Th1 cytokine signal (signal 3) that supports cell proliferation, persistence and potent anti-tumor effects, as was confirmed in our primary and rechallenge in vivo tumor models.

While co-expressing the 4/7ICR with the CAR improved expansion and anti-tumor activity of $\mathrm{T}$ cells in the presence of IL4, this receptor complementation approach of tumor targeting does not address the risk of immune escape due to mutation or loss of the target molecules. Indeed, in patients treated with CD19targeted CARs, the emergence of CD19-negative relapsed disease is an emerging clinical issue [51-54]. However, given the role of MUC1 and IL4 in tumor progression and metastasis [26-28, 55-58], it is highly unlikely that the tumor will downregulate either one or both of these molecules. Nevertheless, to prevent such eventuality, one could consider combining the 4/7ICR with multiple tumor-targeted CARs.

\section{Conclusion}

In this study, we have demonstrated the feasibility of selectively targeting breast cancer using transgenic $\mathrm{T}$ cells equipped to thrive in the suppressive tumor milieu. Our results emphasize the importance of all three signals necessary to fully activate T cells - antigen, co-stimulation, and cytokine for robust and sustained CAR T cell function. The expansion, persistence, potent anti-tumor activity, and safety profile exhibited by the second generation CAR.MUC1 and 4/7ICR modified T cells (2G.4/ 7ICR) support the clinical translation of this approach for the treatment of patients with breast cancer.

\section{Additional file}

Additional file 1: Figure S1. Generation of 2nd generation CAR.MUC1 T cells. (A) Schematic of 2nd generation CAR.MUC1 (2G) retroviral construct. (B) Co-expression of 4/7ICR and 2G CAR as detected by mOrange and anti-$\mathrm{lgG}$, respectively. Summary data (right panel) shows percentage of doublepositive cells (mean \pm SEM, $n=4$ ). (PPTX $298 \mathrm{~kb}$ )

\section{Abbreviations}

1G: 1st generation CAR; ALL: Acute lymphoblastic leukemia; B-CLL: B lymphocyte - Chronic lymphocytic leukemia; CARs: Chimeric antigen receptors; Cr: Chromium; FBS: Fetal bovine serum; FFLuc: Firefly luciferase; GFP: Green fluorescent protein; GVHD: Graft versus host disease; i.v.: Intravenous; ICR: Inverted cytokine receptor; IgG2: Immunoglobulin G2; IL4: Interleukin 4; IL7: Interleukin 7; MDSCs: Myeloid-derived suppressor cells; MUC1: Mucin1; PBMCs: Peripheral blood mononuclear cells; PD-1: Programmed cell death protein 1; s.c.: Subcutaneous; scFv: Single-chain variable fragment; TAA: Tumor associated antigen; Th1: Type 1 helper; Th2: Type 2 helper; TIM3: T-cell immunoglobulin and mucin-domain containing-3; TME: Tumor microenvironment; VNTR: Variable number tandem repeat

\section{Acknowledgments}

We would like to thank Walter Mejia for the artwork and formatting of manuscript figures and are grateful to Texas Children's Hospital Small Animal Imaging Facility, Texas Children's Hospital Flow Cytometry Core Laboratory, and the support of Cell Processing and Vector Production Shared Resource core in the Dan L. Duncan Comprehensive Cancer Center.

\section{Funding}

This work was supported by grants from the NIH-NCI (P01 CA094237, P50 CA126752, P50 CA186784, P30 CA125123), Pancreatic Cancer Action Network Translational Research Grant (16-65-LEEN), Mentored Research Scholars Grants in Applied and Clinical Research (MRSG-14-197-01-LIB) from the American Cancer Society, the Cancer Prevention and Research Institute of Texas Scholar Award (RR170024), the V Foundation for Cancer Research (T2016-006), the Elsa U. Pardee Foundation, the National Pancreas Foundation as well as the Adrienne Helis Malvin Medical Research Foundation in collaboration with Baylor College of Medicine.

\section{Availability of data and materials}

Datasets used and analyzed during the current study are available from the corresponding author upon reasonable request.

\section{Authors' contributions}

The study was conceived by JV and MB. JV, PB and ST designed the experiments. PB, ST, and LD performed experiments and analyzed data. SS and NW characterized and optimized retroviral constructs, performed in vivo experiments, and analyzed data. $\mathrm{VH}$ and PL provided material support. PB, $\mathrm{ST}, \mathrm{AL}$ and JV wrote the manuscript. VH, PL and MB critically reviewed the manuscript. All authors read and approved the final manuscript.

Ethics approval and consent to participate

Collection of human peripheral blood mononuclear cells (PBMCs) were obtained from healthy donors and patients after informed consent on protocols approved by the Institutional Review Board (IRB) at Baylor College of Medicine (H-15152). Mice were housed and treated in accordance with Baylor College of Medicine Animal Husbandry and Institutional Animal Care and Use Committee guidelines (AN-5639).

\section{Competing interests}

The Center for Cell and Gene Therapy at Baylor College of Medicine established a collaboration with Celgene at the time the work was conducted. S.S., A.M.L., and J.F.V. have filed a related patent application. 


\section{Publisher's Note}

Springer Nature remains neutral with regard to jurisdictional claims in published maps and institutional affiliations.

\section{Author details}

${ }^{1}$ Center for Cell and Gene Therapy, Baylor College of Medicine, Texas Children's Hospital and Houston Methodist Hospital, Houston, TX 77030, USA ${ }^{2}$ Interdepartmental Program in Translational Biology and Molecular Medicine, Baylor College of Medicine, Houston, TX 77030, USA. ${ }^{3}$ Department of Pharmacology and Physiology, Faculty of Pharmaceutical Sciences, Chulalongkorn University, Bangkok 10330, Thailand.

Received: 22 January 2018 Accepted: 26 April 2018 Published online: 10 May 2018

\section{References}

1. Siegel RL, Miller KD, Jemal A. Cancer statistics, 2017. CA Cancer J Clin. 2017; 67(1):7-30. https://doi.org/10.3322/caac.21387.

2. Brentjens RJ, Davila ML, Riviere I, Park J, Wang X, Cowell LG, Bartido S, Stefanski J, Taylor C, Olszewska M, et al. CD19-targeted T cells rapidly induce molecular remissions in adults with chemotherapy-refractory acute lymphoblastic leukemia. Sci Transl Med. 2013;5(177):177ra38. https://doi.org/ 10.1126/scitranslmed.3005930.

3. Grupp SA, Kalos M, Barrett D, Aplenc R, Porter DL, Rheingold SR, Teachey DT, Chew A, Hauck B, Wright JF, et al. Chimeric antigen receptor-modified T cells for acute lymphoid leukemia. N Engl J Med. 2013;368(16):1509-18. https://doi.org/10.1056/NEJMoa1215134.

4. Kalos M, Levine BL, Porter DL, Katz S, Grupp SA, Bagg A, June CH. T cells with chimeric antigen receptors have potent antitumor effects and can establish memory in patients with advanced leukemia. Sci Transl Med. 2011; 3(95):95ra73. https://doi.org/10.1126/scitranslmed.3002842.

5. Porter DL, Levine BL, Kalos M, Bagg A, June $\mathrm{CH}$. Chimeric antigen receptormodified T cells in chronic lymphoid leukemia. N Engl J Med. 2011;365(8): 725-33. https://doi.org/10.1056/NEJMoa1103849.

6. Savoldo B, Ramos CA, Liu E, Mims MP, Keating MJ, Carrum G, Kamble RT, Bollard CM, Gee AP, Mei Z, et al. CD28 costimulation improves expansion and persistence of chimeric antigen receptor-modified T cells in lymphoma patients. J Clin Invest. 2011;121(5):1822-6. https://doi.org/10.1172/JCl46110.

7. Wang ZK, Yang B, Liu H, Hu Y, Yang JL, Wu LL, Zhou ZH, Jiao SC. Regulatory T cells increase in breast cancer and in stage IV breast cancer. Cancer Immunol Immunother. 2012;61(6):911-6. https://doi.org/10.1007/s00262-011-1158-4.

8. Watanabe MA, Oda JM, Amarante MK, Cesar VJ. Regulatory T cells and breast cancer: implications for immunopathogenesis. Cancer Metastasis Rev. 2010;29(4):569-79. https://doi.org/10.1007/s10555-010-9247-y.

9. Markowitz J, Wesolowski R, Papenfuss T, Brooks TR, Carson WE 3rd. Myeloidderived suppressor cells in breast cancer. Breast Cancer Res Treat. 2013; 140(1):13-21. https://doi.org/10.1007/s10549-013-2618-7.

10. Shou D, Wen L, Song Z, Yin J, Sun Q, Gong W. Suppressive role of myeloidderived suppressor cells (MDSCs) in the microenvironment of breast cancer and targeted immunotherapies. Oncotarget. 2016;7(39):64505-11. https:// doi.org/10.18632/oncotarget.11352.

11. Lyon DE, McCain NL, Walter J, Schubert C. Cytokine comparisons between women with breast cancer and women with a negative breast biopsy. Nurs Res. 2008;57(1):51-8. https://doi.org/10.1097/01.NNR.0000280655.58266.6c.

12. Turashvili G, Bouchal J, Baumforth K, Wei W, Dziechciarkova M, Ehrmann J, Klein J, Fridman E, Skarda J, Srovnal J, et al. Novel markers for differentiation of lobular and ductal invasive breast carcinomas by laser microdissection and microarray analysis. BMC Cancer. 2007;7:55. https://doi.org/10.1186/ 1471-2407-7-55.

13. Ma XJ, Dahiya S, Richardson E, Erlander M, Sgroi DC. Gene expression profiling of the tumor microenvironment during breast cancer progression. Breast Cancer Res. 2009;11(1):R7. https://doi.org/10.1186/bcr2222.

14. Gaggianesi M, Turdo A, Chinnici A, Lipari E, Apuzzo T, Benfante A, Sperduti I, Di Franco S, Meraviglia S, Lo Presti E, et al. IL4 primes the dynamics of breast Cancer progression via DUSP4 inhibition. Cancer Res. 2017;77(12): 3268-79. https://doi.org/10.1158/0008-5472.CAN-16-3126.

15. Venmar KT, Fingleton B. Lessons from immunology: IL4R directly promotes mammary tumor metastasis. Oncoimmunology. 2014;3(9):e955373. https:// doi.org/10.4161/21624011.2014.955373.

16. Venmar KT, Kimmel DW, Cliffel DE, Fingleton B. IL4 receptor alpha mediates enhanced glucose and glutamine metabolism to support breast cancer growth. Biochim Biophys Acta. 2015;1853(5):1219-28. https://doi.org/10. 1016/j.bbamcr.2015.02.020.

17. Todaro M, Lombardo Y, Francipane MG, Alea MP, Cammareri P, lovino F, Di Stefano AB, Di Bernardo C, Agrusa A, Condorelli G, et al. Apoptosis resistance in epithelial tumors is mediated by tumor-cell-derived interleukin-4. Cell Death Differ. 2008;15(4):762-72. https://doi.org/10.1038/sj.cdd.4402305.

18. Bankaitis KV, Fingleton B. Targeting IL4/IL4R for the treatment of epithelial cancer metastasis. Clin Exp Metastasis. 2015;32(8):847-56. https://doi.org/10. 1007/s10585-015-9747-9.

19. Venmar KT, Carter KJ, Hwang DG, Dozier EA, Fingleton B. IL4 receptor ILR4alpha regulates metastatic colonization by mammary tumors through multiple signaling pathways. Cancer Res. 2014;74(16):4329-40. https://doi. org/10.1158/0008-5472.CAN-14-0093.

20. Hanlon AM, Jang S, Salgame P. Signaling from cytokine receptors that affect TH1 responses. Front Biosci. 2002;7:d1247-54.

21. Freeman BE, Hammarlund E, Raue HP, Slifka MK. Regulation of innate CD8+ T-cell activation mediated by cytokines. Proc Natl Acad Sci U S A. 2012; 109(25):9971-6. https://doi.org/10.1073/pnas.1203543109.

22. Brockhausen I, Yang JM, Burchell J, Whitehouse C, Taylor-Papadimitriou J. Mechanisms underlying aberrant glycosylation of MUC1 mucin in breast cancer cells. Eur J Biochem. 1995;233(2):607-17.

23. Burchell J, Poulsom R, Hanby A, Whitehouse C, Cooper L, Clausen H, Miles D, Taylor-Papadimitriou J. An alpha2,3 sialyltransferase (ST3Gal I) is elevated in primary breast carcinomas. Glycobiology. 1999;9(12):1307-11.

24. Croce MV, Isla-Larrain MT, Demichelis SO, Gori JR, Price MR, Segal-Eiras A. Tissue and serum MUC1 mucin detection in breast cancer patients. Breast Cancer Res Treat. 2003;81(3):195-207. https://doi.org/10.1023/A: 1026110417294

25. Gaemers IC, Vos HL, Volders HH, van der Valk SW, Hilkens J. A statresponsive element in the promoter of the episialin/MUC1 gene is involved in its overexpression in carcinoma cells. J Biol Chem. 2001;276(9):6191-9. https://doi.org/10.1074/jbc.M009449200.

26. Haddon L, Hugh J. MUC1-mediated motility in breast cancer: a review highlighting the role of the MUC1/ICAM-1/Src signaling triad. Clin Exp Metastasis. 2015;32(4):393-403. https://doi.org/10.1007/s10585-015-9711-8.

27. Horm TM, Schroeder JA. MUC1 and metastatic cancer: expression, function and therapeutic targeting. Cell Adhes Migr. 2013;7(2):187-98. https://doi. org/10.4161/cam.23131.

28. Nath S, Mukherjee P. MUC1: a multifaceted oncoprotein with a key role in cancer progression. Trends Mol Med. 2014;20(6):332-42. https://doi.org/10. 1016/j.molmed.2014.02.007.

29. Leen AM, Sukumaran S, Watanabe N, Mohammed S, Keirnan J, Yanagisawa R, Anurathapan U, Rendon D, Heslop HE, Rooney CM, et al. Reversal of tumor immune inhibition using a chimeric cytokine receptor. Mol Ther. 2014;22(6):1211-20. https://doi.org/10.1038/mt.2014.47.

30. Mohammed S, Sukumaran S, Bajgain P, Watanabe N, Heslop HE, Rooney CM, Brenner MK, Fisher WE, Leen AM, Vera JF. Improving chimeric antigen receptor-modified $T$ cell function by reversing the immunosuppressive tumor microenvironment of pancreatic Cancer. Mol Ther. 2017;25(1):249-58. https://doi.org/10.1016/j.ymthe.2016.10.016.

31. Watanabe N, Bajgain P, Sukumaran S, Ansari S, Heslop HE, Rooney CM, Brenner MK, Leen AM, Vera JF. Fine-tuning the CAR spacer improves T-cell potency. Oncoimmunology. 2016;5(12):e1253656. https://doi.org/10.1080/ 2162402X.2016.1253656.

32. Wilkie S, Picco G, Foster J, Davies DM, Julien S, Cooper L, Arif S, Mather SJ, Taylor-Papadimitriou J, Burchell JM, et al. Retargeting of human T cells to tumor-associated MUC1: the evolution of a chimeric antigen receptor. J Immunol. 2008;180(7):4901-9.

33. van Dam PA, Lowe DG, Watson JV, Jobling TW, Chard T, Shepherd JH. Multiparameter flow cytometric quantitation of the expression of the tumorassociated antigen SM3 in normal and neoplastic ovarian tissues. A comparison with HMFG1 and HMFG2. Cancer. 1991;68(1):169-77.

34. Arklie J, Taylor-Papadimitrious J, Bodmer W, Egan M, Millis R. Differentiation antigens expressed by epithelial cells in the lactating breast are also detectable in breast cancers. Int J Cancer. 1981;28(1):23-9.

35. Anurathapan U, Chan RC, Hindi HF, Mucharla R, Bajgain P, Hayes BC, Fisher WE, Heslop HE, Rooney CM, Brenner MK, et al. Kinetics of tumor destruction by chimeric antigen receptor-modified T cells. Mol Ther. 2014;22(3):623-33. https://doi.org/10.1038/mt.2013.262.

36. Nakazawa Y, Huye LE, Salsman VS, Leen AM, Ahmed N, Rollins L, Dotti G, Gottschalk SM, Wilson MH, Rooney CM. PiggyBac-mediated cancer 
immunotherapy using EBV-specific cytotoxic T-cells expressing HER2-specific chimeric antigen receptor. Mol Ther. 2011;19(12):2133-43. https://doi.org/10. 1038/mt.2011.131.

37. Rooney CM, Smith CA, Ng CY, Loftin SK, Sixbey JW, Gan Y, Srivastava DK, Bowman LC, Krance RA, Brenner MK, et al. Infusion of cytotoxic T cells for the prevention and treatment of Epstein-Barr virus-induced lymphoma in allogeneic transplant recipients. Blood. 1998;92(5):1549-55.

38. Bajgain P, Mucharla R, Wilson J, Welch D, Anurathapan U, Liang B, Lu X, Ripple K, Centanni JM, Hall C, et al. Optimizing the production of suspension cells using the G-rex "M" series. Mol Ther Methods Clin Dev. 2014;1:14015. https://doi.org/10.1038/mtm.2014.15.

39. Gutcher I, Becher B. APC-derived cytokines and T cell polarization in autoimmune inflammation. J Clin Invest. 2007;117(5):1119-27. https://doi. org/10.1172/JCI31720.

40. Curtsinger JM, Mescher MF. Inflammatory cytokines as a third signal for $T$ cell activation. Curr Opin Immunol. 2010;22(3):333-40. https://doi.org/10. 1016/j.coi.2010.02.013.

41. Curtsinger JM, Lins DC, Mescher MF. Signal 3 determines tolerance versus full activation of naive CD8 T cells: dissociating proliferation and development of effector function. J Exp Med. 2003;197(9):1141-51. https:// doi.org/10.1084/jem.20021910.

42. Guinan EC, Boussiotis VA, Neuberg D, Brennan LL, Hirano N, Nadler LM, Gribben JG. Transplantation of anergic histoincompatible bone marrow allografts. N Engl J Med. 1999;340(22):1704-14. https://doi.org/10.1056/ NEJM199906033402202.

43. You F, Jiang L, Zhang B, Lu Q, Zhou Q, Liao X, Wu H, Du K, Zhu Y, Meng H, et al. Phase 1 clinical trial demonstrated that MUC1 positive metastatic seminal vesicle cancer can be effectively eradicated by modified anti-MUC1 chimeric antigen receptor transduced T cells. Sci China Life Sci. 2016;59(4): 386-97. https://doi.org/10.1007/s11427-016-5024-7.

44. Maher J, Wilkie S. CAR mechanics: driving T cells into the MUC of cancer. Cancer Res. 2009:69(11):4559-62. https://doi.org/10.1158/0008-5472.CAN-09-0564.

45. Wikie S, van Schalkwyk MC, Hobbs S, Davies DM, van der Stegen SJ, Pereira AC, Burbridge SE, Box C, Eccles SA, Maher J. Dual targeting of ErbB2 and MUC1 in breast cancer using chimeric antigen receptors engineered to provide complementary signaling. J Clin Immunol. 2012;32(5):1059-70. https://doi.org/10.1007/s10875-012-9689-9.

46. Posey AD Jr, Schwab RD, Boesteanu AC, Steentoft C, Mandel U, Engels B, Stone JD, Madsen TD, Schreiber K, Haines KM, et al. Engineered CAR T cells targeting the Cancer-associated Tn-Glycoform of the membrane mucin MUC1 control adenocarcinoma. Immunity. 2016;44(6):1444-54. https://doi. org/10.1016/j.immuni.2016.05.014

47. Razmkhah M, Jaberipour M, Erfani N, Habibagahi M, Talei AR, Ghaderi A. Adipose derived stem cells (ASCs) isolated from breast cancer tissue express IL-4, IL-10 and TGF-beta1 and upregulate expression of regulatory molecules on T cells: do they protect breast cancer cells from the immune response? Cell Immunol. 2011;266(2):116-22. https://doi.org/10.1016/j. cellimm.2010.09.005.

48. Bradley LM, Haynes L, Swain SL. IL-7: maintaining T-cell memory and achieving homeostasis. Trends Immunol. 2005;26(3):172-6. https://doi.org/ 10.1016/j.it.2005.01.004

49. Chazen GD, Pereira GM, LeGros G, Gillis S, Shevach EM. Interleukin 7 is a Tcell growth factor. Proc Natl Acad Sci U S A. 1989:86(15):5923-7.

50. Vera JF, Hoyos V, Savoldo B, Quintarelli C, Giordano Attianese GM, Leen AM, Liu H, Foster AE, Heslop HE, Rooney CM, et al. Genetic manipulation of tumor-specific cytotoxic T lymphocytes to restore responsiveness to IL-7. Mol Ther. 2009;17(5):880-8. https://doi.org/10.1038/mt.2009.34.

51. Maude SL, Frey N, Shaw PA, Aplenc R, Barrett DM, Bunin NJ, Chew A, Gonzalez VE, Zheng Z, Lacey SF, et al. Chimeric antigen receptor T cells for sustained remissions in leukemia. N Engl J Med. 2014;371(16):1507-17. https://doi.org/10.1056/NEJMoa1407222.

52. Ruella M, Barrett DM, Kenderian SS, Shestova O, Hofmann TJ, Perazzelli J Klichinsky M, Aikawa V, Nazimuddin F, Kozlowski M, et al. Dual CD19 and CD123 targeting prevents antigen-loss relapses after CD19-directed immunotherapies. J Clin Invest. 2016;126(10):3814-26. https://doi.org/10. $1172 / \mathrm{JCl} 87366$.

53. Sotillo E, Barrett DM, Black KL, Bagashev A, Oldridge D, Wu G, Sussman R, Lanauze C, Ruella M, Gazzara MR, et al. Convergence of acquired mutations and alternative splicing of CD19 enables resistance to CART-19 immunotherapy. Cancer Discov. 2015;5(12):1282-95. https://doi.org/10.1158/ 2159-8290.CD-15-1020.
54. Turtle CJ, Hanafi LA, Berger C, Gooley TA, Cherian S, Hudecek M, Sommermeyer D, Melville K, Pender B, Budiarto TM, et al. CD19 CAR-T cells of defined CD4+:CD8+ composition in adult B cell ALL patients. J Clin Invest. 2016;126(6):2123-38. https://doi.org/10.1172/JCl85309.

55. Beatson R, Tajadura-Ortega V, Achkova D, Picco G, Tsourouktsoglou TD, Klausing S, Hillier M, Maher J, Noll T, Crocker PR, et al. The mucin MUC1 modulates the tumor immunological microenvironment through engagement of the lectin Siglec-9. Nat Immunol. 2016;17(11):1273-81. https://doi.org/10.1038/ni.3552.

56. Khodarev N, Ahmad R, Rajabi H, Pitroda S, Kufe T, McClary C, Joshi MD, MacDermed D, Weichselbaum R, Kufe D. Cooperativity of the MUC1 oncoprotein and STAT1 pathway in poor prognosis human breast cancer. Oncogene. 2010;29(6):920-9. https://doi.org/10.1038/onc.2009.391.

57. Mungul A, Cooper L, Brockhausen I, Ryder K, Mandel U, Clausen H, Rughetti A, Miles DW, Taylor-Papadimitriou J, Burchell JM. Sialylated core 1 based Olinked glycans enhance the growth rate of mammary carcinoma cells in MUC1 transgenic mice. Int J Oncol. 2004;25(4):937-43.

58. Picco G, Julien S, Brockhausen I, Beatson R, Antonopoulos A, Haslam S, Mandel U, Dell A, Pinder S, Taylor-Papadimitriou J, et al. Over-expression of ST3Gal-I promotes mammary tumorigenesis. Glycobiology. 2010;20(10): 1241-50. https://doi.org/10.1093/glycob/cwq085.

\section{Ready to submit your research? Choose BMC and benefit from:}

- fast, convenient online submission

- thorough peer review by experienced researchers in your field

- rapid publication on acceptance

- support for research data, including large and complex data types

- gold Open Access which fosters wider collaboration and increased citations - maximum visibility for your research: over $100 \mathrm{M}$ website views per year

At BMC, research is always in progress.

Learn more biomedcentral.com/submissions 